\title{
Aksjologiczne podstawy sprawiedliwych wynagrodzeń ${ }^{1}$
}

\author{
Paweł Łuków \\ Zakład Etyki, Wydział Filozofii i Socjologii, Uniwersytet Warszawski
}

„Sprawiedliwość jest pierwszą cnotą instytucji społecznych, podobnie jak prawda w dziedzinie myśli. Teorię nieprawdziwą, bez względu na to, jak by była oszczędna i elegancka, trzeba odrzucić albo poprawić; tak samo prawa i instytucje społeczne, nieważne jak sprawne i dobrze zorganizowane, trzeba zreformować lub znieść, jeśli są niesprawiedliwe"

Rawls (1994, s. 13)

\begin{abstract}
Na tle zarysu podstawowych pojęć z zakresu teorii sprawiedliwości omówionych w części pierwszej artykułu, przedstawiono normatywny charakter zagadnienia sprawiedliwości wynagrodzeń za pracę, sytuując je w kontekście dyskursu praw człowieka oraz idei i wartości społeczeństwa demokratycznego. Odniesienie sprawiedliwości wynagrodzeń do tego dyskursu, wraz z obecną w nim ideą godności ludzkiej, pozwala wskazać w części drugiej artykułu główne zasady etyczne, jakie muszą kształtować akceptowalną koncepcję sprawiedliwych wynagrodzeń, właściwą dla społeczeństwa demokratycznego: szacunek dla jednostek, równość szans i równość pozioma oraz zasada wolności indywidualnej.
\end{abstract}

Słowa kluczowe: sprawiedliwość, wynagrodzenia, społeczeństwo demokratyczne, prawa człowieka

\section{Wprowadzenie}

Rynek - w każdym razie rynek konkurencyjny, znany z modeli ekonomicznych - nie jest domeną sprawiedliwości. Jest układem licznych i złożonych zależności między nabywcami a sprzedającymi, powstających w procesie wymiany towarów i usług, który dąży do równowagi. Istotnym elementem tych zależności

1 Artykuł powstał w ramach projektu badawczego nr 2016/21/B/HS4/02992 pt. Sprawiedliwość wynagradzania, finansowanego ze środków Narodowego Centrum Nauki. 
są wynagrodzenia za pracę. Jeżeli zapłatę za pracę uznać za cenę pracy (zob. Rothschild, 1993, rozdz. 8), a cenę jako rezultat równowagi między podażą a popytem, to na gruncie modelu rynku nie sposób zdefiniować sprawiedliwego wynagrodzenia. Nie dlatego, żeby rynek był z konieczności niesprawiedliwy, ani też nie dlatego, żeby jego uczestnikom brakowało poczucia sprawiedliwości lub byli z gruntu źli. Wolny rynek nie jest domeną sprawiedliwości, ponieważ, po pierwsze, jest tylko modelem, a modeli nie zamieszkują ludzie ani nie ma w nich relacji między ludźmi. Po drugie, istnienia wolnego rynku nie uzasadnia realizowanie ideałów sprawiedliwości. Konkurencyjny rynek nawet nie może korzystać z kategorii sprawiedliwości, gdyż jest instytucją, która pozwala zaspokajać oczekiwania jego uczestników.

$\mathrm{Na}$ pierwszy rzut oka termin „sprawiedliwe wynagrodzenia” brzmi jak oksymoron. W istocie wyrażenie to łączy dwa światy. Dla ekonomisty wynagrodzenia to jeden ze wskaźników stanu gospodarki, który nie może być ani sprawiedliwy, ani niesprawiedliwy. Sprawiedliwość interesuje filozofa i moralistę, dla którego wynagrodzenia to jedno ze społecznie dostępnych dóbr, podlegające dystrybucji zgodnie z określonymi normami etycznymi. Te dwie perspektywy można łączyć, podejmując zagadnienie sprawiedliwych wynagrodzeń definiowanych np. w kategoriach dystrybucji za pomocą dochodu (Rawls, 1994), dobrobytu lub zasobów (Dworkin, 1981a, 1981b), zasług (Lamont, 1997; Feinberg, 2000) czy własności (Hayek von, 1987; Nozick, 1999). Wówczas kwestie ekonomiczne otrzymują kontekst, który każe patrzeć na zagadnienia gospodarcze czy z dziedziny zarządzania personelem z perspektywy szerszej niż równowaga między podażą a popytem.

W niniejszym artykule omówiono dwa podejścia teoretyczne, ujęte w jednej perspektywie badawczej. Zagadnienie sprawiedliwości wynagrodzeń to $\mathrm{w}$ istocie pytanie o ideały i wartości, które określona zbiorowość polityczna chce promować w swej organizacji i funkcjonowaniu. Pod tym względem wynagrodzenia nie są wyjątkiem. Bodaj wszystkie instytucje i regulacje społecznie dostępnych dóbr ucieleśniają tezy normatywne lub wyrażają dążenie do realizacji ideałów lub wartości. Aby kwestię sprawiedliwości wynagrodzeń za pracę podjąć w sposób racjonalnie uporządkowany, należy przedtem nadać pojęciu sprawiedliwości interpretację, co z kolei wymaga refleksji nad pożądanym kształtem życia społecznego.

Aby określić, czego szukamy, pytając o sprawiedliwe wynagrodzenia, trzeba najpierw zdać sobie sprawę z ideałów i wartości, które mamy realizować w życiu społecznym.

Aby zilustrować tę tezę, a także wskazać kierunek stosownych badań, w artykule odniesiono się do wybranych pojęć związanych z kwestią sprawiedliwego wynagrodzenia, znajdujących się w obowiązujących dokumentach regulacyjnych. Ponieważ są to dokumenty z zakresu praw człowieka, ilustracja ta zostanie 
umieszczona we właściwym im paradygmacie normatywnym, który definiuje spektrum stanowisk opartych na prawach człowieka oraz ideałach i wartościach społeczeństwa demokratycznego. W konsekwencji w artykule przedstawiono cztery zasady, które muszą się znaleźć w ujęciu sprawiedliwych wynagrodzeń, należącym do spektrum stanowisk opartych na prawach człowieka oraz ideałach i wartościach społeczeństwa demokratycznego: szacunek dla jednostek, równość szans i równość pozioma oraz wolność indywidualna.

Niniejszy artykuł składa się z dwóch części. W pierwszej przedstawiono zarys zagadnienia sprawiedliwości dyskutowanego na gruncie filozofii moralności i filozofii polityki. Na tym tle pokazano, w jaki sposób zasady sprawiedliwości stanowią kontekst dla takich zagadnień, jak wynagrodzenia za pracę. W części drugiej artykułu omówiono normatywny kontekst praw człowieka oraz ideałów i wartości społeczeństwa demokratycznego, zawarty w obowiązujących w Polsce wybranych dokumentach regulacyjnych odnoszących się wynagrodzeń. Prawa człowieka oraz ideały i wartości społeczeństwa demokratycznego mogą stanowić wartościową podstawę interpretacji pojęcia sprawiedliwości wynagrodzenia za pracę. Następnie przedstawiono konsekwencje tego kontekstu dla rozumienia sprawiedliwości wynagrodzeń.

Celem artykułu nie jest, co oczywiste, sformułowanie szczegółowych zaleceń dotyczących kształtowania sprawiedliwych wynagrodzeń. Chodzi raczej o zarysowanie „programu badawczego” przez wskazanie pytań, które wymagają postawienia, oraz kierunku, jaki powinni obrać ci, którzy zechcieliby udzielić na nie odpowiedzi.

\section{Oblicza sprawiedliwości}

Żądania podyktowane względami sprawiedliwości mają szczególną wagę. Roszczenia poprawy statusu materialnego lub zadowolenia nie mają istotnej siły przekonywania, dopóki nie zostaną włączone w perspektywę sprawiedliwości. Bez tej perspektywy spotykające kogoś zło jest wezwaniem do działania tylko wówczas, gdy wzbudza współczucie czy litość. Kiedy natomiast to samo zło widzimy jako świadectwo lub skutek niesprawiedliwości, żądania poprawy stanu osoby nim dotkniętej nabierają obiektywizującej mocy perswazyjnej.

Gdy na początku XX w. aktywistki ruchów wyzwolenia kobiet, a później działacze na rzecz równości rasowej domagali się równych praw, to swoich wezwań nie uzasadniali jedynie tym, że ich status ekonomiczny czy zadowolenie życiowe jest niższe od tych, które są udziałem członków społeczeństwa cieszących się pełnią praw. Odwołania do szczęścia czy zadowolenia życiowego stanowiły dla 
nich konsekwencję poważniejszego zła, jakim była niesprawiedliwość nierówności i ucisku kobiet lub osób innych ras. Aktywiści zdawali sobie bowiem sprawę, że żądanie równego szczęścia można zbyć kontrargumentem głoszącym, że poczucie szczęścia jest subiektywne i można je uzyskać, godząc się na swój los. Podstawowy argument działaczy na rzecz wyzwolenia kobiet i równości rasowej dotyczył tego, że nierówne prawa są jawną i oburzającą niesprawiedliwością. Zdawali sobie sprawę z tego, że niesprawiedliwość nie jest kwestią przystosowania się jednostek do określonych warunków życia społecznego, osobistych preferencji lub tego, co można zmienić zależnie od upodobań. Niesprawiedliwość to dowód na to, że obecne porządki społeczne są nie do przyjęcia i wymagają zmiany.

Kiedy ktoś głosi, że jest nieszczęśliwy lub że spotkało go nieszczęście i pragnie zmiany, łatwo może się spotkać z odpowiedzią, że jest to jego prywatny problem, z którym musi sobie poradzić, licząc co najwyżej na współczucie i dobroczynność. Kiedy natomiast ktoś twierdzi, że spotyka go niesprawiedliwość, to ogłasza, że porządki społeczne nie są takie, jakie powinny być i że wobec tego to, co go spotyka, nie jest tylko jego osobistą sprawą, ale przede wszystkim sprawą społeczeństwa, w którym żyje. Zło niesprawiedliwości jest złem, które dotyka całą społeczność i za które wszyscy jej członkowie - a zwłaszcza ci najbardziej wpływowi - ponoszą odpowiedzialność moralną. Uznanie czegoś za niesprawiedliwość jest rozpoznaniem spoczywającej na całej zbiorowości (lub wyznaczonych przez nią urzędach) nieuniknionej czy nieuznaniowej powinności usunięcia go.

Rozpoznanie niesprawiedliwości nie jest jednak oczywiste samo przez się. To, czy coś jest niesprawiedliwością czy nieszczęściem, niekoniecznie jest kwestią tzw. nagich faktów, ale może zależeć od tego, jak traktujemy to, co nas spotyka. Takie cechy, jak płeć czy kolor skóry, są dopustem losu w społecznościach sankcjonujących postawy seksistowskie lub rasistowskie. Niższe zarobki kobiet w porównaniu z zarobkami mężczyzn są kwestią pecha kobiet dla kogoś, kto uznaje, że kobiety nadają się wyłącznie do prac podrzędnych i przez to zasługują na niższe wynagrodzenie. Nie będzie to jednak dla niego niesprawiedliwość. Gorsze szanse życiowe osób odmiennej rasy mogą być powodem do współczucia dla kogoś, kto jest przekonany o wyższości swojej rasy, ale nie powodem oburzenia na niesprawiedliwość świata. O tym, czy spotykające kogoś zło uzna się za nieszczęście, z którym jego ofiary muszą sobie radzić, czy niesprawiedliwością, która budzi oburzenie i stanowi dla całego społeczeństwa powód do zmiany, może decydować nasze przekonanie o tym, czy owo zło traktujemy jako niezależne od nas, czy też jako zaniedbanie lub błąd w urządzeniu naszego społeczeństwa (Shklar, 1990, rozdz. 2). Uznając coś za kwestię zrządzenia losu, a nie za niesprawiedliwość, nie stwierdzamy faktu, lecz zachowaniem oświadczamy, że nie zamierzamy nic na nie poradzić: że nie będziemy się starać, aby więcej się nie zdarzyło lub że nie będziemy zwalczać jego 
skutków. To zatem, czy coś uznamy za nieszczęście lub też za niesprawiedliwość, może ujawniać najszczerzej wyznawane ideały i wartości.

„Sprawiedliwość” ma jednak wiele znaczeń. Mówi się np. o sprawiedliwych osobach, uczynkach, wyrokach, organizacjach, prawach czy wynagrodzeniach... I nie wydaje się, by za każdym razem chodziło dokładnie o ten sam rodzaj sprawiedliwości. Przykłady te sugerują rozróżnienie między sprawiedliwością indywidualną a sprawiedliwością społeczną. W pierwszym wypadku chodzi o sprawiedliwość orzekaną o jednostkach, które spełniają lub naruszają normy sprawiedliwości. O sprawiedliwości jednostek można mówić na podstawie ich działań, postaw lub przymiotów charakteru. Natomiast sprawiedliwość społeczna dotyczy norm życia zbiorowego, które regulują relacje między jednostkami, definiując zakres tego, co każdej z nich się należy, i sposoby reagowania przez osoby, urzędy lub organizacje w sytuacjach, gdy rzeczywistość odbiega od tego, czego te normy wymagają. Te dwa obszary sprawiedliwości - indywidualny i społeczny - są ze sobą blisko powiązane, ponieważ zwykle za niesprawiedliwe uważa się te osoby, czyny, postawy itd., które pozostają w konflikcie z normami definiującymi relacje między członkami zbiorowości oraz z normami reagowania na zachwiania tych relacji.

Wraz z Arystotelesem i późniejszą tradycją filozoficzną można wyróżnić dwa rodzaje sprawiedliwości (Arystoteles, 1990, s. 172-173, 2001, s. 1130b-1131a). Normy sprawiedliwości dystrybutywnej lub, jak pisał Stagiryta, rozdzielającej określają to, co się należy każdemu członkowi społeczeństwa i czego wolno od niego oczekiwać niezależnie od jego zasług lub przewinień. Definiują one dystrybucję ciężarów oraz korzyści życia społecznego i w ten sposób ustalają stan normatywnej równowagi społecznej. W prawie normy te są najczęściej wyrażane w postaci praw (uprawnień), wolności i obowiązków obywateli. Normy sprawiedliwości drugiego rodzaju regulują utrzymywanie tej równowagi. Określają sposoby postępowania i prawidła, których przestrzeganie podtrzymuje równowagę społeczną zdefiniowaną normami sprawiedliwości dystrybutywnej lub regulują reagowanie na jej naruszenia. Ta sprawiedliwość, zwana sprawiedliwością retrybutywną lub (za Arystotelesem) wyrównującą, zarówno reguluje transfery dóbr i uprawnień oraz wypełnianie obowiązków, jak i określa sankcje za naruszenia praw lub nieprzestrzeganie obowiązków.

Obydwu rodzajom sprawiedliwości wspólne jest połączenie dwóch idei. Pierwszą jest pojęcie tego, co należne. Normy sprawiedliwości określają, co się komu należy ze względu na jego status członka zbiorowości lub na to, że znajduje się w określonych okolicznościach w następstwie działań własnych bądź działań innych osób lub organizacji. To, co należne, może obejmować świadczenia (np. opieka zdrowotna), warunki (np. praworządne państwo), ciężary (np. podatki), korzyści (np. wynagrodzenia) itp. Można je wyrażać jako prawa podmiotowe (np. 
prawo do zatrudnienia), swobody (np. wolność przemieszczania się), immunitety (np. ochrona miru domowego), powinności rozmaitych podmiotów (np. obowiązek pracodawcy do zapewnienia bezpiecznych warunków pracy) itp. To, co należne konkretnym jednostkom, może zależeć od ich statusu prawnego (np. przynależność do stanu, wiek) lub od okoliczności, w których się znalazły (np. niezdolność do pracy).

Drugą ideą składową sprawiedliwości jest równość. Teorii sprawiedliwości, która nie konceptualizuje zadowalająco równości, nie można uznać za teorię sprawiedliwości (Dworkin, 2000). Jednostki o takim samym statusie i znajdujące się w takiej samej sytuacji należy traktować tak samo: „Jeżeli osobie $A$ należy się $X$, a osoba $B$ nie różni się istotnie (pod względem statusu lub okoliczności) od $A$, to osobie B również należy się X." Zasadę tę można także wyrazić w formule sprawiedliwości formalnej. Formuła ta głosi, że jednostki należące do tej samej kategorii istotnej należy traktować tak samo (Perelman, 1959, s. 37), tj. każdemu, kto należy do tej samej kategorii istotnej, należna jest ta sama ochrona, kara, nagroda, świadczenia ze strony społeczeństwa lub na rzecz innych osób itp. Treść zasad sprawiedliwości - tj. sprawiedliwości konkretnej (C. Perelman wyróżnił sześć jej wersji) - określają definicje kategorii istotnych. Przez wskazanie, kto, w jakich okolicznościach i pod jakim względem podlega równemu traktowaniu, definiują one członkostwo w grupie lub wyróżniają z niej określoną kategorię osób.

Definicje kategorii istotnych w formule sprawiedliwości konkretnej zależą od ideałów i wartości, które kształtują porządki społeczne. Zasada sprawiedliwości merytokratycznej np. głosi, że jednostki o tych samych zasługach powinny otrzymywać takie same nagrody lub wynagrodzenie za takie same osiągnięcia czy zasługi. W zasadzie tej został wyartykułowany pogląd na życie społeczne, wedle którego cechą istotną w alokacji ciężarów i korzyści są zasługi czy osiągnięcia jednostek, a nie np. ich przynależność klasowa czy stanowa. Treść zasad sprawiedliwości obowiązujących w danym społeczeństwie zależy zatem od ideałów i wartości, wedle których jest ono zorganizowane czy też do których realizacji ono aspiruje. To dzięki tym ideałom i wartościom społeczeństwa mają określony „profil aksjologiczny”, wyrażający się m.in. w ich prawodawstwach, kulturach życia publicznego i kulturach organizacyjnych.

Ponieważ normy sprawiedliwości dystrybutywnej określają porządki społeczne danej zbiorowości, normy te stanowią ramę normatywną sprawiedliwości retrybutywnej. To bowiem, jakie porządki społeczne zbiorowość uzna za sprawiedliwe, w kluczowy sposób określi to, jakie przyjmie rozwiązania z zakresu zasad lub regulacji organizacyjnych, które służą alokacji ciężarów i korzyści związanych z interakcjami między członkami społeczeństwa. Na przykład, wysokość opodatkowania dochodu i ewentualnych różnic w opodatkowaniu różnych kategorii 
płatników (definiowanych np. wysokością przychodu) zależy od tego, jaką wagę społeczeństwo przywiązuje m.in. do solidaryzmu społecznego, a więc od tego, jak duże ciężary redystrybucji dochodu uznaje za uzasadnione. Owo uzasadnienie będzie z kolei ulokowane w ideałach i wartościach społecznie uznawanych za określające daną zbiorowość.

Porządki społeczne ustanawiane za pomocą norm sprawiedliwości dystrybutywnej - z teoretycznego punktu widzenia - mogą znaleźć wyraz w konkretnych przepisach prawa lub w praktykach społecznych i organizacyjnych. To jednak, czy i w jakim stopniu wyobrażenia o sprawiedliwości znajdują wyraz w sformalizowanych systemach prawnych, w regulacjach organizacji bądź też w praktykach społecznych lub organizacyjnych, w istotnym stopniu zależy od specyfiki kulturowej lub politycznej społeczeństwa. Zdarza się, że normy sprawiedliwości lub leżące u ich podstawy ideały i wartości nie są artykułowane w sposób wyraźny w postaci oficjalnie promulgowanych przepisów prawa, regulaminów organizacji czy też kodeksów etycznych. Niekiedy należą one do szeroko rozumianej kultury życia publicznego, kultury organizacyjnej lub etosu grupy zawodowej, a ujawniają się w postępowaniu członków tych zbiorowości. Normy sprawiedliwości - wraz ze stojącymi za nimi ideałami i wartościami - to zatem nie tylko wyraźnie sformułowane normy prawne lub organizacyjne, lecz także społecznie podzielane przekonania członków określonej zbiorowości na temat podziału ciężarów i korzyści związanych z życiem w społeczeństwie lub z udziałem we wspólnym przedsięwzięciu oraz zajmowane przez nich postawy wyrastające z tych przekonań. Normy sprawiedliwości niewyrażone oficjalnie, ale należące do kultury życia zbiorowego, często nadają kształt ocenom stanu społeczeństwa lub organizacji i dlatego można je utożsamić z czynnikami składającymi się na poczucie sprawiedliwości ich członków. To poczucie sprawiedliwości może stanowić przymiar w ocenie zarówno norm prawnych, organizacyjnych lub etycznych, jak i działań osób, organizacji lub organów władz publicznych.

\section{Kontekst normatywny wynagrodzeń}

Dokumenty regulacyjne dotyczące rynku pracy obfitują w określenia wynagrodzeń, które zwykle nie są wystarczająco jasne, najczęściej nie są wzajemnie ekwiwalentne, a relacje między nimi nierzadko są problematyczne. Można w nich znaleźć m.in. takie wyrażenia, jak płaca minimalna (minimum wage), sprawiedliwe wynagrodzenie (fair remuneration), sprawiedliwa płaca (just wage) czy też godziwa płaca (living wage). Przykładowo, art. 4. Europejskiej Karty Społecznej (Rada Europy, 1961) głosi, że pracownikom przysługuje prawo do sprawiedliwego wynagrodzenia 
(fair remuneration), które pociąga za sobą zawarte w (wyłączonym z ratyfikacji przez Polskę) ustępie 1 tegoż artykułu prawo do „takiego wynagrodzenia, które zapewni im i ich rodzinom godziwy poziom życia (decent standard of living)" (Rada Europy, 1961). Z kolei Kodeks Pracy (Ustawa..., 1974) daje pracownikom prawo do godziwego wynagrodzenia (nie: do godziwego poziomu czy standardu życia), które ma być realizowane m.in. za pomocą ustalenia minimalnego wynagrodzenia (Ustawa..., 1974, art. 13).

Interpretacja tych pojęć zdecydowanie wykraczałaby poza cele i rozmiary niniejszego artykułu, zwłaszcza jeżeli uwzględnić ich wielowymiarowość i powiązanie zależności ekonomicznych i prawnych (zob. np. Borkowska, 1999; Wratny, 2015). Nie ma też potrzeby rozstrzygać, jakiego rodzaju transfery lub świadczenia pozapłacowe należy zaliczyć do wynagrodzeń; nie jest także konieczne ustalanie relacji między wynagrodzeniami za płacę a rozmaitymi zabezpieczeniami socjalnymi pracowników. W centrum zainteresowania jest tutaj wymiar etyczny wymienionych pojęć związanych z wynagradzaniem za pracę.

Przytoczone pojęcia wyrażają przywiązanie do wartości i ideałów należących do dyskursu praw człowieka i społeczeństwa demokratycznego (Osiatyński, 2011). Kontekst praw człowieka jest wyraźny w Europejskiej Karcie Społecznej (Rada Europy, 1961), która powstała w ramach działania Rady Europy, powołanej do ochrony praw człowieka. W Preambule sygnatariusze tej Karty powołują się na Europejska Konwencje o Ochronie Praw Człowieka i Podstawowych Wolności z dnia 4 listopada 1950 r. (Rada Europy, 1950) oraz na Protokół dodatkowy z dnia 20 marca 1952 r. (Rada Europy, 1952). Realizacji ideałów i zasad państw członków Rady Europy ma służyć m.in. obrona i rozwijanie praw człowieka, a także prawa obywatelskie i polityczne oraz wolności określone w Konwencji (Rada Europy, 1950) i Protokole dodatkowym (Rada Europy, 1952). Celem polityk sygnatariuszy Karty jest stworzenie warunków niezbędnych do realizacji praw wyliczonych w Części I.4, w tym prawa „do sprawiedliwego wynagrodzenia (fair remuneration), wystarczającego dla zapewnienia im [tj. pracownikom], jak i ich rodzinom, godziwego poziomu życia (decent standard of living)" (Rada Europy, 1961).

Z punktu widzenia Europejskiej Karty Społecznej (Rada Europy, 1961) sprawiedliwość wynagrodzeń należy widzieć w kontekście normatywnym praw człowieka oraz ideałów i wartości społeczeństwa demokratycznego. Ze względu na ten kontekst, namysł nad sprawiedliwymi wynagrodzeniami za pracę należy zrelatywizować do perspektywy normatywnej praw człowieka oraz ideałów i wartości społeczeństwa demokratycznego. Odpowiedź na pytanie, czym są sprawiedliwe (fair) wynagrodzenia, wymaga odwołania się do praw człowieka oraz ideałów i wartości społeczeństwa demokratycznego; rozstrzygnięcie, czy dane zasady 
wynagradzania za pracę są sprawiedliwe, wymaga ustalenia, czy zasady te respektują prawa człowieka i realizują ideały i wartości społeczeństwa demokratycznego.

Kontekst praw człowieka oraz ideałów i wartości społeczeństwa demokratycznego, w którym będzie stawiane pytanie o sprawiedliwe wynagrodzenie, ma dwie ważne konsekwencje.

Po pierwsze, interpretacja pojęcia sprawiedliwego wynagrodzenia za pracę zależy od ujęcia teoretycznego, w którym się ono pojawia. W pewnych podejściach teoretycznych pojęciu sprawiedliwych wynagrodzeń nie sposób nadać wyraźnego i precyzyjnego znaczenia, w innych - pojęcie to w ogóle nie wystąpi. Przykładu ujęcia, w którym nie ma miejsca na pojęcie sprawiedliwych wynagrodzeń za pracę, dostarcza analiza doskonale konkurencyjnego rynku; mogą za to występować w niej np. wynagrodzenia efektywne motywacyjnie.

Po drugie - co ważniejsze z punktu widzenia niniejszego artykułu - w kontekście praw człowieka oraz ideałów i wartości społeczeństwa demokratycznego idea sprawiedliwego wynagrodzenia nie ma wymiaru wyłącznie ekonomicznego. Wysokość wynagrodzenia jest w związku z tym tylko jednym z wielu aspektów sprawiedliwego wynagrodzenia. Podobnie tylko jednym z aspektów sprawiedliwego wynagrodzenia za pracę są transfery redystrybucyjne oraz świadczenia zapewniane przez władze publiczne, które stanowią kontekst dla wynagrodzeń i mogą istotnie modyfikować oceny sprawiedliwości wynagrodzeń. Wszystkie te komponenty - jak również otoczenie regulacyjne, organizacyjne i administracyjne - zależą od normatywnego zaplecza, w którym pojawia się zagadnienie sprawiedliwego wynagrodzenia. Z perspektywy norm Rady Europy tym zapleczem są prawa człowieka oraz ideały i wartości społeczeństwa demokratycznego.

Przesadą byłoby oczekiwanie, że odniesienie pojęcia sprawiedliwych wynagrodzeń do praw człowieka oraz ideałów i wartości społeczeństwa demokratycznego pozwoli na ostateczne rozstrzygnięcie pytania o znaczenie tego pojęcia. Pojęcie to lub pojęcia do niego zbliżone pojawiają się w dokumentach autorstwa różnych podmiotów lub gremiów. Możliwe, że nie dysponują jedną wspólną i spójną koncepcją sprawiedliwych wynagrodzeń, ale odnoszą się do tych samych praw, ideałów i wartości. Ponadto, należy zważyć, że poszczególne dokumenty powstały w różnym czasie. Dostrzegane dzisiaj różnice między zawartymi w nich pojęciami sprawiedliwych wynagrodzeń mogą świadczyć o ewolucji tego pojęcia. Oczekiwanie daleko idącej spójności byłoby wówczas bezpodstawne. Należałoby raczej oczekiwać, że idea sprawiedliwego wynagrodzenia za pracę będzie podlegała zmianom oraz interpretacjom i reinterpretacjom wraz ze zmianami społecznymi, technologicznymi i cywilizacyjnymi. Mimo to można zidentyfikować to, co w tej idei najważniejsze: normatywną podstawę i kontekst, jakimi są prawa człowieka oraz ideały i wartości społeczeństwa demokratycznego. Kluczowe znaczenie dla 
właściwego podejścia do kwestii sprawiedliwego wynagrodzenia za pracę będzie miała rekonstrukcja owej podstawy normatywnej. Ona też będzie mogła stanowić podstawę dla konstrukcji znaczenia omawianego pojęcia.

Umieszczenie pojęcia sprawiedliwego wynagrodzenia w kontekście praw człowieka oraz ideałów i wartości społeczeństwa demokratycznego dyskwalifikuje ujęcie omawianego zagadnienia wyłącznie jako funkcjonalne (czy, jak powie filozof, jako konsekwencjalistyczne), tj. takie, w którym uzasadnienia i znaczenia sprawiedliwych wynagrodzeń upatruje się tylko lub głównie w oczekiwanych korzyściach płynących z ich wdrażania (Borkowska, 2004). Sprawiedliwe wynagradzanie za pracę - w odróżnieniu np. od wynagradzania efektywnego lub skutecznego motywacyjnie - stanowi względnie samodzielny postulat normatywny. Tam, gdzie się pojawia, dążenie do sprawiedliwego wynagradzania za pracę nie wynika z przekonania, że sprawiedliwe wynagrodzenia przynoszą większe korzyści gospodarcze dla jednostek bądź zbiorowości niż wynagrodzenia niesprawiedliwe, ale z przeświadczenia, że wynagrodzenia powinny spełniać warunki, których uzasadnienie jest niezależne od dochodowej i kosztowej, motywacyjnej lub społecznej funkcji wynagrodzeń.

Spojrzenie funkcjonalne czy konsekwencjalistyczne jest nakierowane na osiąganie pożądanych celów, a spojrzenie sprawiedliwościowe - rozumiane w kategoriach praw człowieka oraz ideałów i wartości społeczeństwa demokratycznego - na realizowanie pewnego porządku społecznego, którego wartości nie da się sprowadzić do efektywności ekonomicznej lub zarządczej. Historia poucza, że dążenie do efektywności może prowadzić do krzywd jednostek, a nawet zbiorowości. Wynika z niej również, że porządki demokratyczne niejednokrotnie generują koszty, których można by uniknąć, odstępując od przestrzegania praw człowieka oraz realizowania ideałów i wartości społeczeństwa demokratycznego. Jeżeli mimo to pewne społeczeństwa dążą do respektowania praw człowieka oraz realizacji ideałów i wartości społeczeństwa demokratycznego, to czynią to ze względu na przekonanie, iż uzasadnienia funkcjonalne czy konsekwencjalistyczne dla rozwiązań społecznych lub organizacyjnych są niewystarczające. Czym innym jest analiza funkcji wynagrodzenia, a więc dociekanie, jakie korzyści i ciężary mogą generować określone zasady kształtowania go, a czym innym jest postrzeganie wynagrodzenia jako formy realizacji czy egzemplifikacji zasady moralnej lub ideału moralnego. Nie powinny zatem dziwić konflikty między wymogami funkcjonalności i efektywności a wymaganiami sprawiedliwości. Co więcej, nie ma powodów, aby sądzić, że rozstrzygnięcia tych konfliktów zawsze powinny być podyktowane względami efektywności ekonomicznej lub zarządczej. Raczej - jeżeli wziąć pod uwagę fundacyjną rolę praw człowieka oraz ideałów i wartości społeczeństwa demokratycznego dla współczesnych społeczeństw - należałoby oczekiwać, że w wypadku kolizji między efektywnością a prawami człowieka (być 
może poza sytuacjami katastrofalnych zagrożeń dla całych zbiorowości) względy efektywności będą ustępowały przed wymogami owych praw, ideałów i wartości.

Wyczerpująca interpretacja sprawiedliwego wynagrodzenia za pracę z punktu widzenia praw człowieka oraz ideałów i wartości społeczeństwa demokratycznego wymagałaby o wiele szerszego opracowania niż pozwalają na to ramy niniejszego artykułu. Wymagałaby też analizy multidyscyplinarnej, ze szczególnym uwzględnieniem ekspertyzy prawniczej. Można się jednak pokusić o wskazanie elementów etycznych, jakie muszą się znaleźć w dającej się zaakceptować koncepcji sprawiedliwego wynagrodzenia za pracę, która znajduje się w spektrum porządków społecznych kształtowanych przez prawa człowieka oraz ideały i wartości społeczeństwa demokratycznego.

Ponieważ owe niezbędne elementy dotyczą treści etycznej koncepcji sprawiedliwego wynagrodzenia za pracę, konieczne jest zwrócenie uwagi na to, że zagadnienie sprawiedliwego wynagradzania jest problemem normatywnym. Oznacza to, że pojęcie to nie może stanowić elementu modelu wyjaśniającego zachodzące zjawiska. Wyjątkiem od tego ograniczenia jest sytuacja, w której określone wyobrażenie o sprawiedliwych wynagrodzeniach jest tak szeroko uznawane społecznie i traktowane jako oczywiste, że dokonywanie ocen działań i porządków zbiorowych jest, praktycznie rzecz biorąc, powszechne i - stając się „drugą naturą" obywateli niezależnie od ich miejsca w strukturze społecznej, politycznej lub zarządczej - faktycznie kształtuje postawy lub zachowania znakomitej większości uczestników życia zbiorowego. Taka społecznie podzielana koncepcja sprawiedliwych wynagrodzeń staje się rodzajem stałej, która musi wejść w skład analizy realnych procesów społecznych, politycznych, gospodarczych (lub ich połączeń) w postaci opisów zachowań uczestników tych procesów. Dopóki nie istnieje tak szeroko podzielana i praktykowana koncepcja sprawiedliwych wynagrodzeń, proponowane ujęcie sprawiedliwych wynagrodzeń musi mieć charakter normatywny i nie może służyć do wyjaśniana zjawisk. Jest natomiast instrumentem kształtowania rzeczywistości społecznej, politycznej lub gospodarczej.

Konsekwencją przedstawionej konstatacji jest to, że dowolny program badawczy, dzięki któremu na pytanie o sprawiedliwe wynagrodzenie za pracę można uzyskać odpowiedź za pomocą badania opinii pracowników lub menedżerów bądź ich zachowań - jak czyni to np. T. Sapeta (2014) - może przynieść co najwyżej wiedzę o tym, jakie są oczekiwania rozmaitych uczestników życia społecznego. Nie może zaś - bez dołączenia założeń dotyczących normatywnej wagi oczekiwań uczestników życia społecznego - pouczyć o tym, jakie wynagrodzenia należy uznać za sprawiedliwe i wobec tego, czy i jakie zmiany w prawie, regulaminach lub systemach wynagradzania są potrzebne. Pytanie o sprawiedliwe wynagrodzenia wymaga odwołania do norm, które nie tylko dostarczają kontekstu rzeczywistym 
zachowaniom ludzi, lecz także nadają kształt przekonaniom i postawom jednostek wtedy, kiedy występują one w roli pracowników.

Podobnie jak ustalenia opinii na temat sprawiedliwości wynagrodzeń nie mogą stanowić samodzielnej podstawy do określenia, jakie wynagrodzenie jest sprawiedliwe, tak też niewystarczająca jest sama analiza ekonomiczna. Analiza taka może dostarczyć odpowiedzi na temat tego, jakie formy lub systemy wynagradzania pracowników są najbardziej efektywne w porównaniu z alternatywami lub też które z nich generują koszty bądź straty. Analiza ekonomiczna może też wskazać, jakimi instrumentami można poprawić efektywność lub obniżyć koszty. Nie może ona jednak wskazać, który z dostępnych mechanizmów poprawy funkcjonowania organizacji z punktu widzenia wynagrodzeń jest bardziej sprawiedliwy. Oceny tego rodzaju można dokonać z perspektywy normatywnej, która stanowi element względnie niezależny od analizy ekonomicznej.

Jak już wskazano, kontekstem dla myślenia o sprawiedliwych wynagrodzeniach w krajach szeroko rozumianej kultury zachodniej jest dyskurs o prawach człowieka. Na dyskurs ten składają się dwa centralne (chociaż nie jedyne) elementy: godność ludzka i prawa człowieka. Prawa człowieka obejmują zarówno prawa (uprawnienia), jak i wolności indywidualne, które wyznaczają sferę swobody działania jednostek i odpowiadające tym prawom obowiązki władz publicznych. Idea godności ludzkiej odnosi się nie tylko do praw jednostek, lecz także do ograniczeń nakładanych na postępowanie jednostki, które nie naruszają praw innych osób ani nie ich krzywdzą, ale mimo to są niedopuszczalne w społeczeństwie demokratycznym (Beyleveld, Brownsword, 2001). Pomimo często głoszonej tezy (po raz pierwszy oficjalnie sformułowanej w Międzynarodowym Pakcie Praw Obywatelskich i Politycznych z 1966 r. (Międzynarodowy..., 1966a) i równolegle w Międzynarodowym Pakcie Praw Gospodarczych, Społecznych i Kulturalnych z tego samego roku (Międzynarodowy..., 1966b)), że godność jest fundamentem praw człowieka, prawa człowieka i godność ludzka są od siebie nawzajem względnie niezależne i wyznaczają inne, chociaż powiązane rodzaje norm (Łuków, 2018). Obie jednak dostarczają norm społeczeństwa demokratycznego. Obie muszą też znaleźć wyraz w akceptowalnej koncepcji wynagrodzenia za pracę należącej do spektrum stanowisk opartych na prawach człowieka oraz ideałach i wartościach społeczeństwa demokratycznego. Zręby normatywne takiej koncepcji zostaną przedstawione w pozostałej części artykułu.

Akceptowalna koncepcja sprawiedliwego wynagrodzenia musi się opierać na zasadzie szacunku dla jednostki ludzkiej. Szacunek dla jednostki ludzkiej jest sposobem rozpoznania jej godności. Zasada szacunku dla jednostki głosi, że każdemu człowiekowi, niezależnie od jego zasług lub przewinień bądź pełnionej funkcji i miejsca w strukturze społecznej lub organizacji, należy się rozpoznanie 
jako odrębnej jednostki z jej planami, oczekiwaniami i potrzebami. Oznacza to przyjęcie zasady, że sprawy każdego człowieka są dla niego co najmniej tak samo ważne, jak sprawy każdej innej istoty ludzkiej dla niej. W ten sposób szacunek dla jednostki wyznacza granice dla repertuaru zachowań indywidualnych bądź rozwiązań regulacyjnych lub organizacyjnych, które byłyby dyktowane np. względami efektywności. Z uwagi na szacunek do jednostki niedopuszczalne jest np. wykorzystywanie swojej przewagi przetargowej w taki sposób, że potencjalni pracownicy praktycznie nie mają alternatywy i muszą przyjąć ofertę nisko płatnej pracy lub pracy niebezpiecznej bądź w bardzo uciążliwych warunkach. Szacunek dla jednostki ogranicza też repertuar celów, jakie mogą sobie stawiać jednostki lub organizacje. Byłoby np. sprzeczne z szacunkiem dla jednostek prowadzenie działań gospodarczych, które polegają na traktowaniu pracowników jak przedmioty, jak to miało miejsce w epoce nowożytnego niewolnictwa.

Jak pokazują przedstawione przykłady, szacunek dla jednostki wskazuje przede wszystkim granice tego, co dopuszczalne, a więc często będą go wyrażały zakazy. Szacunek dla jednostki może jednak wymagać także pozytywnych działań na rzecz innych, jak np. docenienie czyjegoś wysiłku czy udzielenie wsparcia w realizacji cudzych aspiracji. Oczywiście, szacunek dla innych nie musi pociągać za sobą dążenia do zaspokojenia wszystkich ich aspiracji. Musi jednak oznaczać uznanie, że aspiracje te są ważne co najmniej w taki sposób, że odmowa ich zaspokojenia wymaga uzasadnienia przekonującego osobę zainteresowaną.

Akceptowalna koncepcja sprawiedliwych wynagrodzeń musi się opierać na zasadzie równości. Równe traktowanie jest charakterystyczne zarówno dla szacunku dla jednostki, jak i dla praw człowieka. Bez względu na to, czym zostanie wypełniona koncepcja sprawiedliwości wynagrodzeń należąca do spektrum stanowisk opartych na prawach człowieka oraz ideałach i wartościach społeczeństwa demokratycznego, musi ona objąć szerokie rozumienie równości jako postulatu moralnego oraz normy postępowania i kształtowania rozwiązań regulacyjnych oraz organizacyjnych. Doceniając odrębność jednostek i różnice między nimi, należąca do tego spektrum koncepcja sprawiedliwych wynagrodzeń musi zawierać co najmniej dwa następujące aspekty równości.

Po pierwsze, akceptowalna koncepcja sprawiedliwych wynagrodzeń musi zawierać zasadę równości szans, która wymaga, aby powodzenie jednostki nie było wyłącznie pochodną czynników, które od niej nie zależą. Niesprawiedliwe są porządki społeczne lub organizacyjne, w których powodzenie jednostek jest zdominowane przez czynniki nie pozostające pod ich kontrolą, jak np. ich pochodzenie społeczne lub stopień sprawności. Możliwości awansu, wzrostu wynagrodzenia, poprawy warunków pracy muszą być dostępne dla tych, którzy do nich aspirują na warunkach, które są im znane i respektowane zarówno przez nich, jak i przez 
pozostałych aspirujących. Zasada równych szans oznacza, że przedsięwzięcia zbiorowe - do których należą m.in. działania gospodarcze - należy traktować jako tworzące środowiska nie tylko konkurencji, lecz także współpracy. W środowiskach istniejących dzięki współpracy zasiedlających je istot, postępujących na ogół w zgodzie z podzielanymi zasadami, konkurencja nie zamienia się w bezwzględne dążenie do własnych korzyści. Może natomiast wspierać korzyści wspólne oraz realizowanie wspólnych wartości i ideałów moralnych lub społecznych.

Po drugie, akceptowalna koncepcja sprawiedliwych wynagrodzeń musi zawierać zasadę równości poziomej, tj. zasadę równych korzyści czerpanych przez pracowników zajmujących porównywalne stanowiska w społeczeństwie lub w organizacji bądź wykonujących te same prace lub mających porównywalne osiągnięcia. Oznacza to, że sprawiedliwe wynagrodzenia nie mogą dopuszczać jakiegokolwiek uprzywilejowania lub dyskryminacji, czyli oceniania pracy na podstawie kryteriów, które nie mają przyczynowego związku z właściwym dla określonego pracownika potencjałem realizacji celów realizowanych na rozważanym stanowisku. Różne wynagrodzenie za równą pracę stanowi obrazę jakiegokolwiek systemu wynagrodzeń.

Postulat równości poziomej wiąże się z dwiema trudnościami. Pierwsza dotyczy pytania o rodzaj kryteriów oceny czy wyceny. Kryteria te mogą się odnosić do wydajności pracownika, złożoności powierzonych mu zadań, odpowiedzialności ponoszonej na danym stanowisku itp. Nie wszystkie te kryteria są niekontrowersyjne. Bez względu jednak na przyjęte w organizacji kryteria lub ich kombinację, równość pozioma wymaga, aby były one klarownie zdefiniowane i jednolite w ramach organizacji. Druga trudność dotyczy różnic wynagrodzeń między organizacjami, w których za porównywalną pracę pracownicy mogą otrzymywać istotnie różne wynagrodzenia. Jest zrozumiałe, że tego rodzaju różnice są jednym z elementów składających się na konkurencyjność pracodawców na rynku pracy oraz świadczonych przez nich usług lub dostarczanych towarów. Usunięcie takich różnic skutkowałaby pogorszeniem funkcjonowania organizacji i jej szans powodzenia na rynkach. Różnice te nie mogą jednak być zbyt duże. Wyznaczenie akceptowalnych granic takich zróżnicowań wykracza poza perspektywę jednej organizacji i należy do zadań, które należą do zakresu odpowiedzialność całych społeczeństw lub wyznaczonych przez nie agend.

Akceptowalna koncepcja sprawiedliwych wynagrodzeń musi się opierać na zasadzie wolności indywidualnej. Sprawiedliwość wynagrodzeń wiąże się z ich akceptowalnością, co jest jedną z form realizacji wolności jednostki ludzkiej. Wybór miejsca zatrudnienia, możliwość negocjowania (w określonych granicach) wynagrodzenia i warunków świadczenia pracy należą do podstawowych obszarów wolności obywateli społeczeństwa demokratycznego. Tezę tę bardzo dobrze 
ilustruje relacja między art. 4 ust. 1 Europejskiej Karty Społecznej a art. 4 ust. 2 Europejskiej Konwencji Praw Człowieka, który zakazuje zmuszania do świadczenia pracy przymusowej lub obowiązkowej (Unia Europejska, 2012, art. 5 ust. 2). Brak swobody w sferze wpływu pracownika na miejsce zatrudnienia lub wysokość wynagrodzenia przypomina warunki pracy niewolniczej, a w pewnych okolicznościach może być z nią tożsamy. O ile pewne ograniczenia wyboru miejsc zatrudnienia, możliwości negocjowania wynagrodzenia i warunków świadczenia pracy są nieuniknione, o tyle praktyczny (tj. taki, gdy skorzystanie z opcji uznawanej za lepszą pociąga za sobą niewspółmiernie wysokie koszty czy poświęcenia ze strony pracownika, jak np. konieczność wielogodzinnego dojeżdżania do pracy) brak wyboru w tym zakresie oznacza pracę porównywalną z niewolniczą.

Zapewnienie wolności jednostki w kontekście pytania o sprawiedliwość wynagrodzeń za pracę ma dwa wymiary: ogólnospołeczny i organizacyjny. Systemowy brak wyboru miejsca zatrudnienia, możliwości negocjowania wynagrodzenia i warunków świadczenia pracy przez obywateli - np. w sytuacji monopolistycznego pracodawcy w kraju lub regionie - to istotne zaniedbanie ze strony władz publicznych odpowiedzialnych za politykę gospodarczą. Z kolei brak analogicznych możliwości w ramach zatrudniającej organizacji nie musi ograniczać wolności potencjalnych pracowników, jeżeli na danym terenie pracę oferuje wystarczająco wielu pracodawców konkurujących o tych samych pracowników.

\section{Podsumowanie}

Korzystając z wypracowanych na gruncie filozofii moralności i filozofii polityki pojęć dotyczących sprawiedliwości, w artykule przedstawiono zagadnienie sprawiedliwego wynagrodzenia za pracę jako nieuchronnie „ulokowane” w kontekście normatywnym wyobrażeń o sprawiedliwości, które mają zastosowanie do całych społeczeństw, a nie tylko do określonych grup ludzi bądź organizacji. Te wyobrażenia stanowią naturalną podstawę interpretacji idei sprawiedliwego wynagrodzenia. W społeczeństwach demokratycznych taką podstawą są prawa człowieka oraz idee i wartości społeczeństwa demokratycznego, zawarte w międzynarodowych dokumentach regulacyjnych dotyczących wynagrodzeń. Odniesienie kwestii sprawiedliwości wynagrodzenia za pracę do dyskursu o prawach człowieka wraz z obecną w nim ideą godności ludzkiej pozwala wskazać główne zasady, jakim musi być wierna akceptowalna koncepcja sprawiedliwych wynagrodzeń, należąca do spektrum podejść opartych na prawach człowieka oraz ideałach i wartościach społeczeństwa demokratycznego. Są to zasady szacunku dla jednostek, równości szans i równości poziomej oraz zasada wolności indywidualnej. 
Wymienione zasady wymagają, oczywiście, doprecyzowania i operacjonalizacji tak, aby służyć jako dyrektywy przy tworzeniu akceptowalnej koncepcji sprawiedliwego wynagrodzenia za pracę. Przede wszystkim konieczne jest uwzględnienie odmienności stosowania tych zasad do społeczeństw w procesie rządzenia $\mathrm{w}$ porównaniu $\mathrm{z}$ ich zastosowaniem do organizacji w procesie zarządzania nimi. Ponadto, konieczne jest rozwiązanie problemów funkcjonowania całych społeczeństw i organizacji zgodnie z tymi zasadami, związanych z wzajemną interakcją tych dwóch domen. Nie ulega jednak wątpliwości, że owocne podjęcie kwestii sprawiedliwego wynagrodzenia nie może się ograniczyć do analizy prawnej, badania postaw lub analizy ekonomicznej, ale musi objąć badania w sferze normatywnej. We współczesnych społeczeństwach demokratycznych sferę tę wyznacza dyskurs o prawach człowieka, na który składają się nie tylko regulacje, lecz także badania praw człowieka, związane z nimi praktyki społeczne i rozwiązania organizacyjne. Uwagi te stanowią zaledwie drobny przykład tego, co może stanowić punkt wyjścia dla badań nad sprawiedliwością wynagrodzenia za pracę.

\section{Bibliografia}

Arystoteles (1990). Etyka nikomachejska. Warszawa: PWN.

Arystoteles (2001). Etyka nikomachejska. Warszawa: Wydawnictwo Naukowe PWN.

Beyleveld, D., Brownsword, R. (2001). Human dignity in bioethics and biolaw. Oxford: Oxford University Press.

Borkowska, S. (2004). Strategie wynagrodzeń. Kraków: Oficyna Ekonomiczna.

Borkowska, S. (1999). Wynagrodzenie godziwe. Koncepcja i pomiar. Warszawa: IPISS.

Dworkin, R. (2000). Sovereign virtue: The theory and practice of equality. Cambridge, MA: Harvard University Press.

Dworkin, R. (1981a). What is Equality? Part 1: Equality of Welfare. Philosophy \& Public Affairs, 10, 185-246.

Dworkin, R. (1981b). What is Equality? Part 2: Equality of Resources. Philosophy \& Public Affairs, 10, 283-345.

Feinberg, J. (2000). Justice and Personal Desert. W: M. Friedman, L. May, K. Parsons, J. Stiff (red.), Rights and Reason: Essays in Honor of Carl Wellman. Dordrecht: Springer Netherlands, 221-250.

Hayek von, F.A. (1987). Konstytucja wolności. Warszawa-Wrocław: Wers.

Lamont, J. (1997). Incentive Income, Deserved Income and Economic Rents. Journal of Political Philosophy, 5, 26-46.

Łuków, P. (2018). A Difficult Legacy: Human Dignity as the Founding Value of Human Rights. Human Rights Review, 19(3), 313-329.

Międzynarodowy Pakt Praw Obywatelskich i Politycznych (1966a). Dz.U. z 1977 r. Nr 38, poz. 167. 
Międzynarodowy Pakt Praw Gospodarczych, Społecznych i Kulturalnych (1966b). Dz.U. z 1977 r. Nr 38, poz. 169.

Nozick, R. (1999). Anarchia, państwo, utopia. Warszawa: Aletheia.

Osiatyński, W. (2011). Prawa człowieka i ich granice. Kraków: Społeczny Instytut Wydawniczy Znak.

Perelman, C. (1959). O sprawiedliwości. Warszawa: PWN.

Rada Europy (1961). Europejska Karta Społeczna. ETS No. 163. Turyn.

Rada Europy (1950). Europejska Konwencja o Ochronie Praw Człowieka i Podstawowych Wolności. ETS No. 005. Rzym.

Rada Europy (1952). Protokół dodatkowy do Konwencji o Ochronie Praw Człowieka i Podstawowych Wolności. ETS No. 009. Paryż.

Rawls, J. (1994). Teoria sprawiedliwości. Warszawa: Wydawnictwo Naukowe PWN.

Rothschild, K. (1993). Employment, Wages and Income Distribution. London: Routledge. Sapeta, T. (2014). Koncepcja wynagrodzenia godziwego - mit czy rzeczywistość? Marketing i Rynek, 5, 1199-1205.

Shklar, J.N. (1990). The faces of injustice. New Haven: Yale University Press.

Unia Europejska (2012). Karta praw podstawowych Unii Europejskiej. Dz. Urz. 2012/C 326/02.

Ustawa z dnia 26 czerwca 1974 r. - Kodeks pracy. Dz.U. Nr 24, poz. 141 z późn. zm. Wratny, J. (2015). Prawo do wynagrodzenia za pracę w świetle zasad sprawiedliwości i równości. Annales Universitatis Mariae Curie-Skłodowska, sectio G (Ius), 62, 298-315.

\section{Summary}

\section{Axiological Bases of Fair Remuneration}

Against the background of some key concepts belonging to the theory of justice, the paper identifies the normative nature of the question of fair remuneration and situates it in the context of the human rights discourse and the values and ideals of a democratic society. The human rights discourse, together with its idea of human dignity, makes it possible to identify some of the key ethical principles which must shape a plausible concept of fair remuneration in a democratic society: respect for persons, equality of opportunity and horizontal equality, and the principle of individual freedom.

Keywords: justice/fairness, remuneration/pay, democratic society, human rights 


\section{Prof. dr hab. Paweł Łuków}

Filozof i etyk; Kierownik Zakładu Etyki w Instytucie Filozofii Uniwersytetu Warszawskiego; kierownik studiów magisterskich Bioetyka na Uniwersytecie Warszawskim; Kierownik Centrum Bioetyki i Bioprawa UW; Redaktor Naczelny półrocznika Etyka; autor licznych artykułów poświęconych etyce kantowskiej, filozofii medycyny i etyce życia publicznego. 